\title{
Groundwater-based Irrigation in the US - Challenges and Progress
}

\author{
Blessing Masasi
}

Department of Agriculture, University of Arkansas at Pine Bluff, 1200 N. University Dr, Pine Bluff, AR 71601; masasib@uapb.edu

\begin{abstract}
Even though groundwater-based irrigation has increased agricultural productivity and economic activity in the United States (US), the current rate of groundwater withdrawals from major aquifers could significantly affect the sustainability of agricultural production systems in the near future. In the major agricultural regions, producers are now facing challenges to irrigate to meet full crop water needs. There is an increasing need to strategize irrigation management under various climatic and environmental conditions to optimize water use in agriculture while optimizing crop yields. This study reviews some of the major challenges facing irrigated agriculture in the US and the potential measures to ensure the sustainability of groundwater-based irrigation. Identified challenges included diminishing quantity and quality of groundwater resources, frequent droughts, low adoption rates of precision irrigation technologies, and rising energy requirements for irrigation abstractions. Irrigation efficiency improvements, shifting to high water use efficiency crops, wastewater reuse, groundwater monitoring, availing incentives, and policy changes, were identified as promising water management strategies to ensure irrigation sustainability. The success of these strategies will depend on the uptake and adoption by the producers in the affected agricultural regions.
\end{abstract}

Keywords: groundwater depletion; precision water management; adoption; sustainability; Ogallala aquifer; Arkansas Delta; Mississippi River Valley Alluvial Aquifer

\section{Introduction}

Irrigated agriculture plays a vital role in producing food, feed, and fiber in the United States (US) [1]. In addition, irrigation has consistently been the largest single consumer of water in the US, accounting for $80-90 \%$ of total consumptive water use [2]. However, pressure on available water resources has increased because of population growth, changing climate, and excessive depletion of water resources, particularly groundwater [3]. Resultantly, water has become the major limiting factor for crop production [3,4]. Major agricultural regions in the US, such as the Ogallala Aquifer region of the High Plains and the Arkansas Delta, are facing groundwater problems. Producers now have water supply challenges to irrigate to meet the full crop water needs under current irrigation and cropping scenarios [5].

Groundwater from aquifers is used in about $60 \%$ of the irrigated area in the US, making it an essential source of irrigation [6]. However, severe groundwater withdrawals from the aquifers have resulted in significant declines in well capacities and increased pumping costs [7]. Previous studies have reported that some major agricultural regions in the US will have severe water scarcity within the next 20 to 30 years if no significant changes in irrigation management are adopted [8,9]. Therefore, as water resources continue to dwindle, improved agricultural water management will become crucial to guarantee the continued success of irrigated agriculture [10]. Sustainable water management under dwindling groundwater resources will require innovative irrigation strategies that enhance agricultural water use efficiency [11]. 
Considering the contribution of irrigated agriculture to the economy and for food and fiber production in the US, there is no doubt that irrigation management should be sustainable. Therefore, there is a need to interrogate the status quo of groundwater-based irrigation to find ways that promote irrigation sustainability. Understanding the challenges and successes of groundwater-based irrigation is relevant and vital for managing modern agriculture, particularly under diminishing natural resources, increasing population, and accelerating climate change. Thus, this study details the current challenges and progress of groundwater-based irrigated agriculture in the US and discusses some of the potential areas that can be addressed, including approaches that may sustain the benefits from irrigation.

\section{Water Resources - Challenges and Progress}

\subsection{High Plains of the Ogallala Aquifer Region}

The High Plains (HP) of the Ogallala Aquifer region is one of the most productive irrigated regions in the US [9,12]. Approximately $97 \%$ of irrigation water in the HP region comes from the Ogallala aquifer, as surface water resources are insufficient for this purpose $[7,13]$. However, decades of pumping with limited recharge have resulted in severe depletion of the aquifer, and its water levels have continuously declined in many parts of the region [14,15]. For instance, widespread declines of greater than $15 \mathrm{~m}$ have been reported in the eastern parts of Colorado and western Kansas [16]. Because of the water level declines, well capacities in the region have significantly dropped, and producers face serious water challenges to irrigate to meet crop water demands [17]. With the current groundwater withdrawal rates from the Ogallala aquifer, indications are that the aquifer will fail to support irrigation within the next 30 years [6]. Additionally, excessive groundwater depletion in the HP has affected surface water sources in the region. Dennehy et al. [18] reported a reduction of stream flows and drying up of surface water channels due to excessive groundwater withdrawals. Frequent extreme droughts have also exacerbated these occurrences because of reduced groundwater recharge and surface water resources [7].

In addition to water quantity challenges, deterioration of groundwater quality was also identified as a potential threat to irrigated agriculture in the HP region. Chaudhuri and Ale [19] reported contamination of groundwater in the HP of Texas caused by both anthropogenic and natural processes. Their study highlighted that groundwater contamination from natural processes was stimulated by extensive groundwater pumping for irrigation from deep underlying layers. Furthermore, chemicals from irrigated croplands were also identified as drivers to the rising salinity levels in the Ogallala aquifer, exceeding environmental thresholds. Tilman et al. [20] explained that return flows from irrigated croplands have salts, nutrients, and pesticides carried into surface and groundwater. These have repercussions, particularly to the downstream and the environment.

Over the past several decades, significant strides were made towards increasing the efficiency of irrigation systems through technological improvements to combat water scarcity in the HP region [1,10]. Most gravity irrigation systems were converted to more efficient center pivot and subsurface irrigation systems [7]. Nonetheless, this has been a partial triumph towards water conservation, and more irrigation management efforts will undoubtedly be required [10]. Weinheimer et al. [12] identified strategic irrigation management as a critical factor in conserving water resources in the region. Management strategies involving changing crop types and cultivars, sowing date, planting density, irrigation amount, and scheduling were pinpointed as potential adaptation measures to cope with water scarcity [21]. Chen et al. [9] underscored the need to shift from water-intensive such as corn to low water-demanding crops like cotton, grain sorghum, and winter wheat to extend the lifespan of the Ogallala aquifer. Although cotton production has expanded into traditional corn production areas in the HP, more 
conversions from corn to drought-tolerant crops could result in additional water savings in the region [7].

In addition to better crop choices, Bordovsky et al. [22] stated that producers in the $\mathrm{HP}$ region should adopt management practices that involve low irrigation levels instead of the current irrigation practices. This argument agrees with other studies that have proposed adopting irrigation management strategies that target maximizing production per unit of water instead of the traditional thrust of production per unit area [23]. In line with these views, several studies have highlighted the potential of deficit irrigation as a strategy to reduce irrigation water use to cope with water scarcity [24]. Incorporating various monitoring technologies to estimate crop water demand, soil moisture availability, irrigation application rates, and precipitation in cropping fields could significantly enhance deficit irrigation [12]. However, Fereres and Soriano [23] emphasized that deficit irrigation strategies still need to be developed for most crops. Their study highlighted a lack of knowledge on whether the deficit irrigation strategy can be used effectively over extended periods in the growing season.

In other studies, irrigation timing was cited as an important factor in advancing agricultural water conservation [25]. Proper selection of the first and last irrigation date based on the soil type, crop type, crop growth stage, and evapotranspiration rate could lead to significant water savings. Although simple in theory, this is a complex process requiring strategic and tactical planning [26]. The timing of the earliest and last irrigation affects the level of water conservation. First irrigation applications should be made to minimize water losses, while last irrigation should ensure no significant water deficits and overall yield losses. Starting and termination timing for irrigation may be facilitated by using crop simulation models and soil water monitoring, possibly using soil moisture sensors [3].

\subsection{Arkansas Delta Region}

Arkansas ranks third in irrigated cropland in the US and is one of the major producers of valuable crops like rice, soybean, corn, cotton, wheat, and grain sorghum. Irrigated crop production is concentrated mainly in the Arkansas Delta, located in the eastern areas of the state. The Mississippi River Valley Alluvial Aquifer (MRVAA) is the primary source of irrigation water for crop production in the region. According to Evett et al. [27], irrigation from wells on individual farm tracts in eastern Arkansas accounts for $85 \%$ of the water removed from MRVAA. However, decades of pumping coupled with the region's geology that limit recharge have resulted in significant groundwater decline and aquifer depletion [27-29]. Previous studies have reported that the MRVAA is one of the aquifers with the highest rate of daily water withdrawals in the US. Large areas of eastern Arkansas have been designated as critical groundwater zones [30,31]. Clark et al. [32] projected further aquifer depletions across large areas in the Arkansas Delta by 2050 if current pumping practices continue unabated.

In addition to aquifer overdraft due to continuous groundwater pumping, excessive irrigation activities in the Arkansas Delta are causing contamination of water resources through surface runoff and deep percolation losses [28]. Furthermore, like most southern US regions, Arkansas has experienced droughts in recent years [33]. Extended summertime droughts are becoming more frequent in the Arkansas Delta despite the relatively high annual rainfall $[27,30]$. Due to the importance of irrigated agriculture in Arkansas, the continued groundwater declines of the MRVAA, droughts, and water quality issues in the Delta will have devastating impacts on the region's economy.

The predominant irrigation method in the Arkansas Delta region is furrow irrigation on row crops. Several water management strategies have been developed to improve irrigation efficiency and conserve water in this region. Surge irrigation is one such strategy that improves infiltration and reduces surface runoff and deep percolation losses [34]. Other strategies that have significantly gained prominence are the Tailwater Recovery System and On-Farm Water Storage Systems. Combining these two systems 
allow irrigation and stormwater runoff at the field to be collected and stored, and used for irrigation during the dry periods, thereby saving groundwater [34;35]. Cultivation of cover crops to improve soil health has also increased significantly in the region. Some producers have also started using precision irrigation technologies like soil moisture sensors to schedule irrigation [29].

\section{Discussions}

\subsection{Irrigation Strategies}

Arkansas ranks third in irrigated cropland in the US and is one of the major producers of valuable crops like rice, soybean, corn, cotton, wheat, and grain sorghum. Several strategies can be implemented to ensure that groundwater-based irrigation is sustainable in the US, and these range from agronomic, institutional, and infrastructure improvements and adjustments. Sustainable irrigation strategies target conserving water and energy resources while maximizing crop production without negative environmental effects. Colaizzi et al. [7] evaluated several approaches to reduce groundwater withdrawals while maintaining crop productivity in the HP. Their study proposed using weather-based irrigation scheduling, converting gravity irrigation systems to center pivot irrigation, and shifting from high water demanding crops such as corn to less water-intensive crops like grain sorghum and cotton. High water-use efficient and drought-tolerant crops could be appropriate in arid and semi-arid environments like the HP as they promote water conservation [36,37].

Peterson and Ding [38] found that conversion of flood to more efficient subsurface drip irrigation systems decreased irrigation applications per acre and groundwater withdrawals. Scanlon et al. [6] argued that efficiency improvements in groundwater-reliant irrigation areas would reduce groundwater depletion. The adoption of efficient irrigation systems promotes energy conservation and reduces the potential for waterlogging. Waterlogging reduces crop yields and causes groundwater contamination due to the leaching of agricultural pesticides and fertilizers to the aquifers [20].

In places of limited water supplies, deficit irrigation strategies based on soil-crop characteristics, climate, and management practices could be used to conserve water while maintaining or improving crop yields [23]. However, as Fereres and Soriano [23] reported, there is a need for investigating various deficit irrigation strategies that can result in yield optimization while reducing irrigation water use. These deficit irrigation strategies may be developed using crop models such as AquaCrop [39,40] and the Decision Support System for Agrotechnology Transfer [41].

Alley [42] pointed out the scientific uncertainty of the impacts of groundwater pumping on surface water sources and highlighted that even though both surface and groundwater are connected in the hydrological cycle, they are generally managed separately under different laws and administrative institutions. In the HP, Sophocleous [43] argued that fragmented institutional arrangements are inadequate to address water supply and quality and recommended forming an interstate groundwater commission. Such a commission will provide an opportunity for water managers, researchers, and policymakers to formulate integrated strategies for managing water resources. This approach concurs with the argument by Alley [42], who highlighted the need to utilize available data in the context of water resources sustainability in an integrated way involving feedbacks among monitoring, simulation, scientific studies, and management approaches. Fortunately, groundwater data is available for most regions in the US collected from an extensive network of monitoring wells managed by the United States Geological Survey (USGS). Therefore, groundwater data availability in the US presents an opportunity to model and evaluate several groundwater management scenarios to develop appropriate strategies that ensure the sustainable use of this limited resource. Such information will assist policymakers in determining the proper mix of regulations, incentives, and public investments that encourage technological developments and farm-level adoption of methods that will ensure irrigation sustainability [20,44]. 
Irrigation often leads to environmental degradation through salinization, surface and groundwater pollution, and loss of ecosystem services [45]. Dennehy et al. [18] emphasized the importance of water quality to the overall health of the agricultural economy in HP. Their study highlighted that there had been a general focus on water availability while ignoring water quality, and yet quality in many instances limits the intended use of the water. Water quality is critical in both the HP and the Arkansas Delta, where groundwater is conjunctively used by many sectors, including public water supply. If contaminated, the groundwater may not be suitable for human consumption due to the high concentration of salts, nitrates from agricultural croplands. Therefore, even though available water quantity is of great importance in formulating sustainable irrigation strategies, it is necessary to also include water quality issues in the planning and management of water resources in these regions. Thus, there is a need to investigate the impacts of various irrigation management practices on groundwater contamination to formulate regulations.

Reuse of drainage water from irrigated croplands, wastewater, and proper disposal systems like evaporation ponds should be promoted to reduce adverse effects of irrigation on the environment [45]. However, there have been debates surrounding the impacts of wastewater reuse on the environment and human health. For example, De Fratuire et al. [37] highlighted that reuse of drainage water might have adverse effects on the environment due to the accumulation of soluble salts in the soil. Nonetheless, farmers can blend drainage water with fresh water supplies or use it in sequence with freshwater irrigations [46].

It is important to note that irrigation may only be sustainable if producers adopt these strategies. Adoption requires the producers to be convinced that they can derive benefits from the recommended irrigation strategies and management practices. Low adoption rates pose problems in implementing water and environmental conservation policies and programs. For instance, producers may make decisions on crop choices based on the market value of the crop. In the HP, there is a tendency by producers to grow high-value crops such as corn and soybean, which are water-intensive, thereby making water conservation efforts challenging to implement. In this situation, policymakers may avail incentives, including increasing market value for crops such as cotton and sorghum, which consume less water. Universities, state, and federal agencies may employ comprehensive extension programs to educate producers on the implications of overexploitation of water resources on the future success of irrigated agriculture and the environment. Emphasizing the importance of ecosystem services with practical references could motivate producers to be more efficient.

Just like in any field, "you cannot manage what you cannot measure." However, many producers lack information on how much water they are pumping and how efficient their irrigation systems are. In Oklahoma, for instance, only $16 \%$ of irrigation wells have meters to monitor groundwater withdrawals [47]. Approximately $88 \%$ of the farms in Oklahoma use subjective and nonscientific irrigation scheduling methods. Thus, most producers do not have the information regarding whether they are over-irrigating or under-irrigating. Applying less irrigation reduces yields. On the other hand, over-irrigating translates to energy overuse and environmental degradation through the leaching of salts and agricultural chemicals. Policies and regulations that compel producers to have meters on their irrigation wells to monitor groundwater withdrawals should be put in place to sustain groundwater-based irrigation in the US.

In many instances, irrigation systems like center pivot systems will continue to irrigate during rainfall events, mainly due to technological inadequacies of the systems. In this case, the opportunity for crops to utilize rainfall will be lost. These circumstances usually result in loss of nutrients due to deep percolation and waterlogging, which lead to contamination of water resources, yield reduction, and wastage of energy. Producers should take advantage of the new weather monitoring technologies available on the market to attach to their irrigation systems. Extension agencies should intensify the 
education of producers on the benefits of new technologies and linking them with the manufacturers and service providers.

Several studies have reported that decision support systems and monitoring tools may enhance water conservation in irrigated agriculture [23]. Adeyemi et al. [48] revealed that incorporating monitoring tools such as soil, plant, and weather sensors into irrigation decision support systems like crop simulation models could be critical to achieving optimal use of limited water resources. However, the adoption of monitoring tools has been slow in the US. For instance, less than $10 \%$ of the irrigated farms use soil moisture sensors or other advanced on-farm water management decision tools [2]. In Oklahoma, Taghvaeian [47] reported that $8 \%$ of the producers utilize the daily evapotranspiration (ET) products despite the availability of extensive and well-maintained Mesonet weather stations. Many factors like cost and level of education could be contributing to the low adoption levels. Sadler et al. [49] reported that some of the available precision tools were developed without considering the producers' skill sets, knowledge, and abilities, making it difficult for their adoption and effective use. As Taghvaeian [47] highlighted, producers can increase technology adoption for irrigation management; however, more research on applying these technologies is needed to enhance confidence.

\subsection{Irrigation Research Direction and Approaches}

The current rate of groundwater declines evidenced in major agricultural regions in the US will negatively affect regional economies, rural communities, and the agricultural industries that depend on agricultural production [12]. However, just like in many water-limited regions, water conservation is possible provided new water management strategies are adopted [50]. Thus, research is needed to explore various irrigation management strategies to determine how they affect crop yield and water use and ultimately select the best possible options for conserving water.

According to Douglas-Mankin [51], simulation studies are one of the future research focus areas that would help address the needs of decision-makers as they work to ensure the sustainability of land and water resources. Simulation models may benefit water and irrigation management to quantify the effects of water on yield because of their capacity to integrate the impacts of soils, weather, and irrigation management on crop production at various scales $[3,40]$. While field research is equally important, valuable information can be obtained from modeling different irrigation management practices [40]. Various alternatives can be evaluated quickly and more efficiently than field experiments $[9,36]$. In most cases, field experiments could not easily assess management alternatives and their potential outcomes, and generated recommendations are not generalizable for larger scales [52].

Additionally, several studies have noted a drop in field research on cropping systems; thus, simulation models may fill that gap and could be applied to optimize irrigation under limited water supplies while reducing risk and uncertainty in crop production [3,23]. With historical long-term weather data, crop models provide a platform to evaluate the effectiveness and trade-offs among different irrigation scenarios, thereby allowing timely decision-making and quality recommendations for producers $[11,21]$. Nevertheless, Evett and Tolk [53] reported a gap between what crop simulation models can do and what policymakers and water managers need to address. Incorporating producers' objectives and the potential operational limitations in irrigation modeling studies is more likely to generate relevant and reliable information, ultimately enhancing adoption [11]. These views suggest that there is potential for more application of crop models in irrigation research and management.

Crop models should have a balance between accuracy and complexity to be useful [54]. Some models often require more specific crop data that may not be easily obtainable to perform simulations [55]. For instance, some studies have pointed out that the Decision Support System for Agrotechnology Transfer (DSSAT) is complex and requires 
numerous input parameters for making thorough evaluations of crop growth and development and water dynamics [56]. On the other hand, the AquaCrop model developed by the Food and Agricultural Organization (FAO) of the United Nations balances accuracy and usability [40]. This crop model simulates yield in response to water management and has a relatively low requirement of specific inputs [36]. According to Araya et al. [52], this model could be used to design and study the effect of water management options, including irrigation management, planting dates, and planting densities. Despite its potential, very few studies are available that have utilized the AquaCrop model for irrigation management research in the US.

\section{Conclusions}

Irrigation is essential for crop production and economic growth in many regions in the US, including the HP and the Arkansas Delta, and thus, its sustainability is imperative. However, the diminishing of the groundwater resources in both quantity and quality and competition for water resources across sectors have threatened the sustainability of groundwater-based irrigated agriculture in the US. This study outlined some of the challenges facing irrigation in the HP and the Arkansas Delta and the possible measures that can ensure the sustainability of groundwater-based irrigation in these regions. Overall, there is potential for enhancing water through strategic crop and irrigation management. Additionally, education, incentives, regulation, monitoring, evaluation, and efficiency improvements were identified as potential drivers to ensure irrigation sustainability. However, for irrigation to be sustainable, researchers, policymakers, water managers, extension workers, environmentalists and most importantly, producers should come together and find lasting solutions to the current water resources challenges. Further research should investigate various options highlighted in this study using integrated approaches, as this could help formulate effective policies and water management strategies.

Funding: This research received no external funding.

Acknowledgments: The author wishes to thank Dr. Saleh Taghvaeian, Associate Professor in the Department of Biosystems and Agricultural Engineering at Oklahoma State University, for his continued support.

Conflicts of Interest: The author declares no conflict of interest.

\section{References}

1. Howell, T.A. Enhancing water use efficiency in irrigated agriculture. Agronomy journal. 2001, 93(2), 281-289.

2. Schaible G.; Aillery M. Water conservation in irrigated agriculture: Trends and challenges in the face of emerging demands. USDA-ERS Economic Information Bulletin. 2012, 1(99).

3. Kisekka I.; DeJonge K.C.; Ma L.; Paz J.; Douglas-Mankin K. Crop modeling applications in agricultural water management. Transactions of the ASABE. 2017, 60(6), 1959-64.

4. Rogers D.H.; Elliott R.L. Irrigation scheduling using crop growth simulation, risk analysis, and weather forecasts. Transactions of the ASAE. 1989, 32(5), 1669-77.

5. Lamm F.R.; Stone K.C.; Dukes MD; Howell T.A.; Robbins JW; Mecham B.Q. Emerging technologies for sustainable irrigation: selected papers from the 2015 ASABE and IA irrigation symposium. Transactions of the ASABE. 2016, 59(1), 155-61.

6. Scanlon B.R.; Faunt C.C.; Longuevergne L.; Reedy R.C.; Alley W.M.; McGuire V.L.; McMahon P.B. Groundwater depletion and sustainability of irrigation in the US High Plains and Central Valley. Proceedings of the national academy of sciences. 2012, 109(24), 9320-9325.

7. Colaizzi P.D.; Gowda PH; Marek T.H.; Porter D.O. Irrigation in the Texas High Plains: A brief history and potential reductions in demand. Irrigation and Drainage. 2009, 58(3), 257-274.

8. Haacker E.M.; Kendall A.D.; Hyndman D.W. Water level declines in the High Plains Aquifer: Predevelopment to resource senescence. Groundwater. 2016, 54(2), 231-242.

9. Chen Y.; Marek G.W.; Marek T.H.; Moorhead J.E.; Heflin K.R.; Brauer D.K.; Gowda PH; Srinivasan R. Assessment of alternative agricultural land use options for extending the availability of the Ogallala Aquifer in the Northern High Plains of Texas. Hydrology. 2018, 5(4), 53.

10. Evett S.R.; Colaizzi P.D.; O'Shaughnessy SA; Lamm F.R.; Trout T.J.; Kranz W.L. The future of irrigation on the US Great Plains. In Proceedings of the 26th Annual Central Plains Irrigation Conference, Burlington, CO. 2014, 2-25. 
11. Greaves G.E.; Wang Y.M. Identifying irrigation strategies for improved agricultural water productivity in irrigated maize production through crop simulation modelling. Sustainability. 2017, 9(4), 630.

12. Weinheimer J.; Johnson P.; Mitchell D.; Johnson J.; Kellison R. Texas High Plains initiative for strategic and innovative irrigation management and conservation. Journal of Contemporary Water Research \& Education. 2013, 151(1), 43-49.

13. Smidt S.J.; Haacker E.M.; Kendall A.D.; Deines J.M.; Pei L.; Cotterman K.A.; Li H.; Liu X.; Basso B.; Hyndman D.W. Complex water management in modern agriculture: Trends in the water-energy-food nexus over the High Plains Aquifer. Science of the Total Environment. 2016, 566, 988-1001.

14. Howell T.A.; Schneider A.D.; Evett S.R. Subsurface and surface microirrigation of corn - Southern High Plains. Transactions of the ASAE. 1997, 40(3), 635-41.

15. Yazar A.; Howell T.A.; Dusek D.A.; Copeland K.S. Evaluation of crop water stress index for LEPA irrigated corn. Irrigation Science. 1999, 18(4), 171-180.

16. Stone L.R.; Schlegel A.J. Yield-water supply relationships of grain sorghum and winter wheat. Agronomy Journal. 2006, 98(5), 1359-1366.

17. Stone L.R.; Lamm F.R.; Schlegel A.J.; Klocke N.L. Storage efficiency of off-season irrigation. Agronomy journal. 2008, 100(4), 1185-1192.

18. Dennehy K.F.; McMahon P.B.; Gurdak J.J.; Bruce B.W. Water quality and the availability and sustainability of water supplies in the High Plains aquifer. Water-Quality Assessment of the High Plains Aquifer, 1999-2004: US Geological Survey Professional Paper. 2004, 1749.

19. Chaudhuri S.; Ale S. Long term (1960-2010) trends in groundwater contamination and salinization in the Ogallala aquifer in Texas. Journal of Hydrology. 2014, 513, 376-390.

20. Tilman D.; Cassman KG; Matson P.A.; Naylor R.; Polasky S. Agricultural sustainability and intensive production practices. Nature. 2002, 418(6898), 671-7.

21. Debaeke P.; Aboudrare A. Adaptation of crop management to water-limited environments. European Journal of Agronomy. 2004, 21(4), 433-446.

22. Bordovsky J.P.; Mustian J.T.; Cranmer A.M.; Emerson C.L. Cotton-grain sorghum rotation under extreme deficit irrigation conditions. Applied engineering in agriculture. 2011, 27(3), 359-371.

23. Fereres E.; Soriano M.A. Deficit irrigation for reducing agricultural water use. Journal of experimental botany. 2007, 58(2), 147-59.

24. Geerts S.; Raes D. Deficit irrigation as an on-farm strategy to maximize crop water productivity in dry areas. Agricultural water management. 2009, 96(9), 1275-1284.

25. Masasi B.; Taghvaeian S.; Boman R.; Datta S. Impacts of irrigation termination date on cotton yield and irrigation requirement. Agriculture. 2019, 9(2), 39.

26. Unger P.W.; Howell T.A. Agricultural water conservation-A global perspective. Journal of crop production. 2000. $2(2)$, 1-36.

27. Evett S.; Carman D.; Bucks D. Expansion of irrigation in the mid-south United States: Water allocation and research issues. In Proceedings, 2nd international conference on irrigation and drainage, water for a sustainable world-limited supplies and expanding demand, Phoenix, AZ. 2003, 247-260.

28. Reba M.L.; Massey J.H.; Adviento-Borbe M.A.; Leslie D.; Yaeger M.A.; Anders M.; Farris J. Aquifer depletion in the lower Mississippi River Basin: Challenges and solutions. Journal of Contemporary Water Research E Education. 2017, 162(1), 128-139.

29. West GH; Kovacs K. Addressing groundwater declines with precision agriculture: an economic comparison of monitoring methods for variable-rate irrigation. Water. 2017, 9(1), 28.

30. Robinson P.; Clemmens A.J.; Carman D.K.; Dalmut Z.; Fortner T. Irrigation development in eastern Arkansas: Water supplies, uses, and efficiencies. In Proceedings of the Second International Conference on Irrigation and Drainage, Las Vegas, NV. 2003, $12-15$.

31. Spencer G.D.; Krutz L.J.; Falconer L.L.; Henry W.B.; Henry C.G.; Larson E.J.; Pringle III HC; Bryant C.J.; Atwill R.L. Irrigation Water Management Technologies for Furrow-Irrigated Corn that Decrease Water Use and Improve Yield and On-Farm Profitability. Crop, Forage E Turfgrass Management. 2019, 5(1), 1-8.

32. Clark B.R.; Westerman D.A.; Fugitt D.T. Enhancements to the Mississippi Embayment Regional Aquifer Study (MERAS) groundwater-flow model and simulations of sustainable water-level scenarios. US Geological Survey Scientific Investigations Report. 2013, 5161(29), 2013.

33. Watkins K.B. The 2010 and 2011 Arkansas drought experience. Choices. 2012, 27(316-2016-6348).

34. Quintana-Ashwell N.; Gholson D.M.; Krutz L.J.; Henry C.G.; Cooke T. Adoption of water-conserving irrigation practices among row-crop growers in Mississippi, USA. Agronomy. 2020, 10(8), 1083.

35. Yaeger M.A.; Massey J.H.; Reba ML.; Adviento-Borbe M.A.; Trends in the construction of on-farm irrigation reservoirs in response to aquifer decline in eastern Arkansas: Implications for conjunctive water resource management. Agricultural water management. 2018, 208, 373-83.

36. Masasi B.; Taghvaeian S.; Gowda PH; Warren J.; Marek G. Simulating soil water content, evapotranspiration, and yield of variably irrigated grain sorghum using AquaCrop. JAWRA Journal of the American Water Resources Association. 2019, 55(4), 976-993.

37. De Fraiture C.; Fayrap A.; Unver O.; Ragab R. Integrated water management approaches for sustainable food production. Irrigation and Drainage. 2014, 63(2), 221-231.

38. Peterson J.M.; Ding Y. Economic adjustments to groundwater depletion in the high plains: Do water-saving irrigation systems save water? American Journal of Agricultural Economics. 2005, 87(1), 147-159. 
39. Steduto P.; Raes D.; Hsiao T.C.; Fereres E.; Heng L.K.; Howell T.A.; Evett S.R.; Rojas-Lara B.A.; Farahani HJ; Izzi G.; Oweis T.Y. Concepts and applications of AquaCrop: the FAO crop water productivity model. In Crop modeling and decision support; Springer, Berlin: Heidelberg, 2009; pp. 175-191

40. Masasi B.; Taghvaeian S.; Gowda PH; Marek G.; Boman R. Validation and application of AquaCrop for irrigated cotton in the Southern Great Plains of US. Irrigation Science. 2020, 38(5), 593-607.

41. Jones J.W.; Hoogenboom G.; Porter C.H.; Boote K.J.; Batchelor W.D.; Hunt L.A.; Wilkens P.W.; Singh U.; Gijsman A.J.; Ritchie J.T. The DSSAT cropping system model. European journal of agronomy. 2003, 18(3-4), 235-265.

42. Alley W.M. Tracking US groundwater: reserves for the future? Environment: Science and Policy for Sustainable Development. 2006, 48(3), 10-25.

43. Sophocleous M. Groundwater management practices, challenges, and innovations in the High Plains aquifer, USA-lessons and recommended actions. Hydrogeology Journal. 2010, 18(3), 559-575.

44. Evans R.G.; Sadler E.J. Methods and technologies to improve efficiency of water use. Water resources research. 2008, 44(7).

45. Wichelns D.; Oster J.D. Sustainable irrigation is necessary and achievable, but direct costs and environmental impacts can be substantial. Agricultural water management. 2006, 86(1-2), 114-127.

46. Rhoades J.D.; Kandiah A.; Mashali A.M. The use of saline waters for crop production-FAO irrigation and drainage paper 48. Food and Agriculture Organization of the United Nations. 1992, 133.

47. Taghvaeian, S. Irrigated Agriculture in Oklahoma. Oklahoma Cooperative Extension Service. 2015, BAE-1530.

48. Adeyemi O.; Grove I.; Peets S.; Norton T. Advanced monitoring and management systems for improving sustainability in precision irrigation. Sustainability. 2017, 9(3), 353.

49. Sadler E.J.; Evans R.; Stone K.C.; Camp CR. Opportunities for conservation with precision irrigation. Journal of soil and water conservation. 2005, 60(6), 371-378.

50. Zwart S.J.; Bastiaanssen W.G. Review of measured crop water productivity values for irrigated wheat, rice, cotton and maize. Agricultural water management. 2004, 69(2), 115-133.

51. Douglas-Mankin K.R. Current research in land, water, and agroecosystems: ASABE journals 2017 year in review. Transactions of the ASABE. 2018, 61(5), 1639-1651.

52. Araya A.; Kisekka I.; Holman J. Evaluating deficit irrigation management strategies for grain sorghum using AquaCrop. Irrigation science. 2016, ;34(6), 465-481.

53. Evett S.R.; Tolk J.A. Introduction: Can water use efficiency be modeled well enough to impact crop management? Agronomy Journal. 2009, 101(3), 423-425.

54. Monteith J.L. The quest for balance in crop modeling. Agronomy Journal. 1996, 88(5), 695-697.

55. García-Vila M.; Fereres E. Combining the simulation crop model AquaCrop with an economic model for the optimization of irrigation management at farm level. European Journal of Agronomy. 2012, 36(1), 21-31.

56. Modala N.R.; Ale S.; Rajan N.; Munster C.L.; DeLaune P.B.; Thorp K.R.; Nair S.S.; Barnes EM. Evaluation of the CSM-CROPGRO-Cotton model for the Texas rolling plains region and simulation of deficit irrigation strategies for increasing water use efficiency. Transactions of the ASABE. 2015, 58(3), 685-696. 